\title{
Serum Electrolytes Disturbances in Type 2 Diabetic Patients
}

\author{
Jivanraj Bohara ${ }^{1}$, Saroj Kunwar ${ }^{2}$, Govinda Akela Poudel ${ }^{3}$, Shyam Raj Joshi ${ }^{4}$, \\ Shashi Gurung ${ }^{5}$
}

${ }^{1}$ Laboratory Instructor, Modern Technical College, Lalitpur, Nepal

${ }^{2,3}$ Assistant Professor, Modern Technical College, Lalitpur, Nepal

${ }^{4}$ Laboratory In charge, Baitadi District Hospital Molecular Laboratory, Baitadi, Nepal

${ }^{5}$ Laboratory Technologist, School of Medical Sciences (SMS) Banasthali, Kathmandu, Nepal

Corresponding Author: Jivanraj Bohara

\begin{abstract}
Introduction: Type II diabetes mellitus is considered as a global epidemic that can lead to the complication related to renal, retinal and vascular system. Measurement of ions like sodium, potassium and chloride can be useful as a marker for the patient's susceptibility to develop diabetes related complications. Thus, our study focuses on observing the electrolyte imbalances in type II diabetes patients.

Methods: This was a comparative cross-sectional study conducted at Star Hospital, Lalitpur, Nepal. A total of 400 (200 type II diabetic and 200 healthy subjects) participants were enrolled. Blood sample was collected and fasting plasma glucose (FPG) was measured by glucose oxidase-peroxidase method and serum sodium $\left(\mathrm{Na}^{+}\right)$, potassium $\left(\mathrm{K}^{+}\right)$and chloride $\left(\mathrm{Cl}^{-}\right)$were measured by ion selective electrode method.

Results: In type 2 diabetic patients serum sodium was decreased while potassium and chloride was found to be increased than healthy subjects. We found negative correlation between fasting plasma glucose and sodium $(\mathrm{r}=-0.36, \mathrm{p}=0.001)$. On the other hand positive correlation was found between fasting plasma glucose with potassium and chloride $(\mathrm{r}=0.194, \mathrm{p}=0.006$ and $\mathrm{r}=0.36, \mathrm{p}=0.001)$ respectively.

Conclusion: The serum sodium was found to be decreased with the rise in fasting plasma glucose. On the flip side, serum potassium and chloride was increased with the increase in fasting plasma glucose level. Therefore management of type 2 diabetes must include electrolyte profile test to monitor increase or decrease of electrolyte concentration to prevent the patient's risk of developing the diabetes associated complications.
\end{abstract}

Keywords: Diabetes mellitus, electrolytes, glucose, sodium, potassium, chloride

\section{INTRODUCTION}

Diabetes mellitus is a major and increasing global public health importance. [1] It is characterized by chronic hyperglycemia which results from defective insulin action or secretion or both. ${ }^{[2]}$ Persons with diabetes are at increased risk for chronic complications which may affects many organ systems and are responsible for majority of morbidity and mortality associated with the disease. It is a major cause of renal failure, cardiovascular damage and retinopathy. As the disease progress, patients are at higher risk for the development of various complications including metabolic imbalances, blood vessels degeneration, effect on electrolyte concentration and offset of the proportion of electrolytes. ${ }^{[3,4]}$

Electrolytes play an important role in the maintaining acid-base balance, membrane potential, blood clotting, muscle 
contraction, nerve conduction and controlling body fluids. Its imbalances have become a leading cause of impairment of human health. ${ }^{[5]}$ Major electrolytes present in intracellular fluid are potassium, magnesium, phosphate and sulfate whereas sodium, chloride and bicarbonate in extracellular fluid. ${ }^{[6]}$ Sodium is mainly associated with acid-base regulation, maintenance of osmotic equilibrium as well as uniform distribution and conservation of body fluids. Potassium is mainly responsible for the neuromuscular excitability, acid-base balance, cardiac action and acts as co-factor for the enzyme pyruvate kinase. Chloride helps in fluid balance inside and outside cells, maintaining blood volume and acidbase balance.

The disturbed electrolyte distribution may affect the course of diabetes and its management. ${ }^{[7]}$ The relation between blood glucose and electrolytes is complex and is related to a number of other factors like age and associated conditions. ${ }^{[8]}$ Moreover, diabetic nephropathy which is one of the complications of diabetes is characterized by impaired renal function can lead to electrolyte imbalance, as elevated blood sugar damages the nephrons, thereby altering electrolyte absorption and reabsorption. ${ }^{[9]}$ Number of studies have shown the association between electrolytes level and diabetes. ${ }^{[8,12-15]}$ So, this study was conducted to find out the relation between fasting plasma glucose and electrolytes and to investigate the electrolytes disturbances in type 2 diabetic patients.

\section{MATERIALS AND METHODS Study Subjects:}

It was a comparative cross-sectional study conducted on 400 subjects, Out of which 200 were known cases of type 2 diabetic patients (male-114, female-86; mean age 53.08 \pm 13.21 years) diagnosed from the endocrinology department of Star hospital and 200 were healthy controls (male-103, female-97; mean age $52.17 \pm 12.85$ years) from out patients department of hospital with no history of diabetes. Persons with conditions like renal disease, saline therapy, hemolytic disease, other chronic illness, alcohol intake, pregnancy were excluded from this study.

All the participants were given an explanation of the nature of study and informed consent was obtained. They completed a questionnaire covering information on age, gender, medical and family history of chronic diseases. This study was approved by the Institutional review committee (IRC) of Nepal Health Research Council (NHRC). All the analytical tests were performed at Department of Biochemistry, Star hospital, Lalitpur, Nepal.

\section{Sample Collection:}

A total of $6 \mathrm{ml}$ venous blood sample was drawn from each individual following aseptic precaution, using a disposable syringe. All the participants were at minimum 8-10 hours fasting state. About $2 \mathrm{ml}$ of blood was distributed in a sodium fluoride anticoagulant containing tube for the estimation of plasma glucose level and remaining blood was taken in a gel tube to obtain serum for the analysis of electrolytes.

\section{Clinical Analysis:}

Serum analysis of $\mathrm{Na}^{+}, \mathrm{K}^{+}$and $\mathrm{Cl}^{-}$ was performed by ion selective electrode using Nova stat profile prime electrolyte analyzer. Plasma glucose was estimated by glucose oxidase-peroxidase method using human glucose liquicolor, the concentration was measured spectrophotometrically by STAT Fax 3300 semiautoanalyzer. $^{[10,11]}$

\section{Statistical Analysis:}

Results are presented as mean \pm SD. Statistical significance and difference between test and control values were evaluated by Independent t-test. Pearson's correlation test was applied to show correlation between variables. Statistical analysis was performed by using SPSS version 16. P-value <0.05 was considered statistically significant. 


\section{RESULTS}

A total of 400 participants were included in our study, among which 200 were healthy individuals (control) and 200 were type 2 diabetic patients (case). The total number of male participant was 217 and total number of female participant was 183. The mean age of studied population was (49.62 \pm 13.954 years), type 2 diabetics (53.08 \pm 13.21 years) Versus healthy control (52.17 \pm 12.85 years). The mean FPG level in type 2 diabetics $(154.71 \pm 48.80 \mathrm{mg} / \mathrm{dL})$ was significantly higher than healthy control $(94.02 \pm 15.64 \mathrm{mg} / \mathrm{dL})$ with $\mathrm{p}$ value 0.001 . Similarly, serum potassium level in type 2 diabetics $\quad(4.287 \pm 0.5 \mathrm{mmol} / \mathrm{L}) \quad$ was significantly higher in comparison to healthy control group $(4.038 \pm 0.366 \mathrm{mmol} / \mathrm{L})$ $(\mathrm{p}=0.001)$. Also, the mean difference between serum chloride level of type 2 diabetic patients $(109.71 \pm 3.90)$ and healthy control (107.84 \pm 3.291$)$ was statistically significant with $\mathrm{p}$ value of 0.001 . On the other hand, the mean serum sodium level in type 2 diabetics $(139.03 \pm 3.27 \mathrm{mmol} / \mathrm{L})$ is significantly lower than healthy control $(140.08 \pm 2.85 \mathrm{mmol} / \mathrm{L})$ with $\mathrm{p}$ value 0.001 . (Table 1)

Table 1: Age and Electrolytes Concentration among Study Population with p-value

\begin{tabular}{|l|l|l|l|}
\hline Parameters & $\begin{array}{l}\text { Type 2 diabetic } \\
\text { patients (mean } \pm \\
\text { SD) }\end{array}$ & $\begin{array}{l}\text { Healthy } \\
\text { controls (mean } \\
\pm \text { SD) }\end{array}$ & $\begin{array}{l}\text { P- } \\
\text { value }\end{array}$ \\
\hline Age (years) & $53.08 \pm 13.21$ & $52.17 \pm 12.85$ & 0.76 \\
\hline $\begin{array}{l}\text { FPG } \\
(\mathrm{mg} / \mathrm{dL})\end{array}$ & $154.45 \pm 48.80$ & $94.02 \pm 15.64$ & 0.001 \\
\hline $\begin{array}{l}\mathrm{Na}^{+} \\
(\mathrm{mmol} / \mathrm{L})\end{array}$ & $139.09 \pm 3.27$ & $140.08 \pm 2.85$ & 0.001 \\
\hline $\mathrm{K}^{+}(\mathrm{mmol} / \mathrm{L})$ & $4.29 \pm 0.51$ & $4.04 \pm 0.37$ & 0.001 \\
\hline $\begin{array}{l}\mathrm{Cl}^{-} \\
(\mathrm{mmol} / \mathrm{L})\end{array}$ & $109.71 \pm 3.90$ & $107.84 \pm 3.29$ & 0.001 \\
\hline
\end{tabular}

The correlation between fasting plasma glucose versus sodium, potassium and chloride in type 2 diabetic patient was observed using Pearson's correlation test. The correlation coefficient ( $r$ ) between fasting plasma glucose and sodium was found to be negative which was statistically significant $(\mathrm{p}=0.001, \mathrm{r}=-0.36)$. (Figure 1) On the flip side, positive correlation was found between FPG and potassium which was also statistically significant at $(\mathrm{p}=0.006$, $\mathrm{r}=0.194$ ). (Figure 2) Likewise, positive correlation was also found between FPG and chloride which was statistically significant at $(\mathrm{p}=0.001, \mathrm{r}=0.36)$. (Figure 3 )

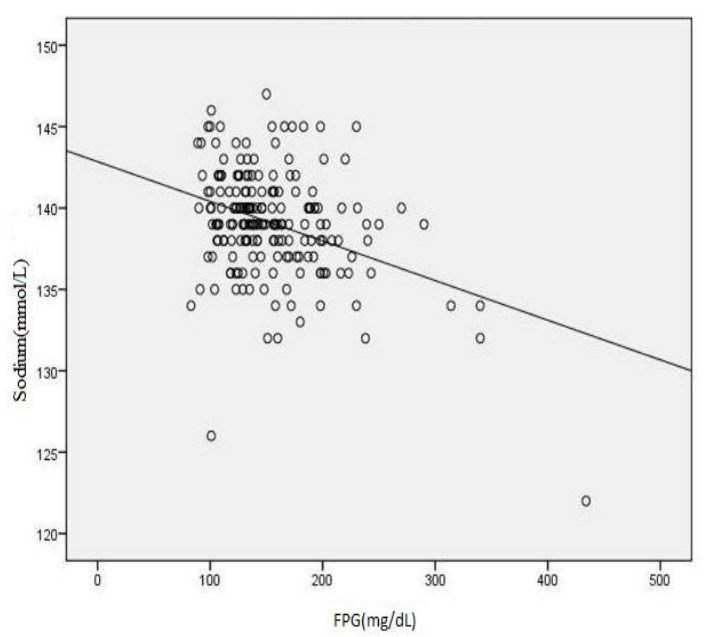

Figure 1: Graph showing correlation between FPG \& serum sodium in type 2 diabetes patients

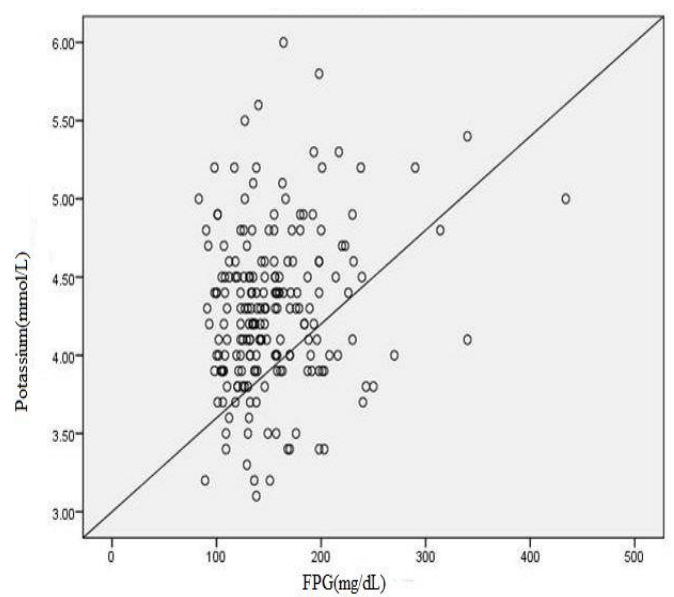

Figure 2: Graph showing correlation between FPG \& serum potassium in type 2 diabetes patients

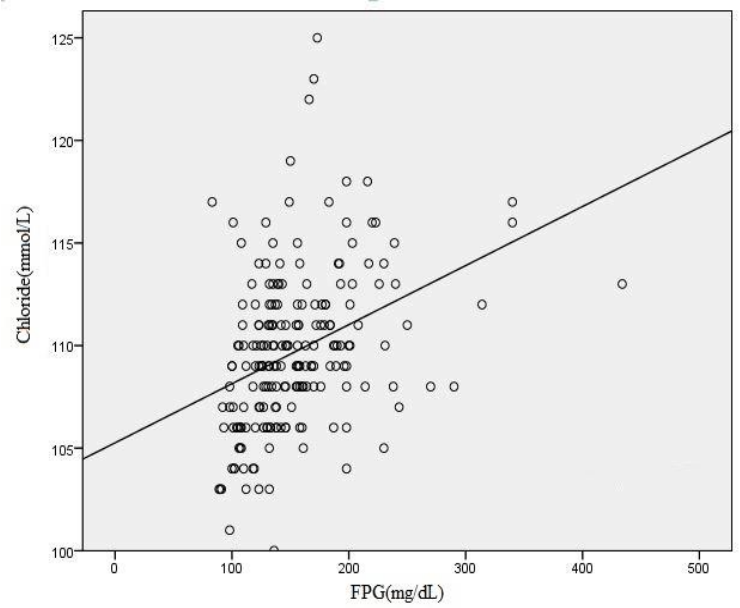

Figure 3: Graph showing correlation between FPG \& serum chloride in type 2 diabetes patients 


\section{DISCUSSION}

Diabetes mellitus is a complex multi-system endocrine disorder which can lead to potentially devastating complication that can affect all age group worldwide. ${ }^{[16]}$ Electrolyte imbalance occurs in type 2 diabetes results from hyperglycemia. Several previous studies have shown disturbed electrolyte distribution in serum of type 2 diabetic patients. In our study we have found significantly decreased serum sodium level in type 2 diabetic patients than healthy control. It is supportive to study by Muhammad SS et al. (2005), Jameil N AL (2014), Wang et al. (2013) and Talabani N (2015) they also found significant hyponatraemia in diabetic patients than healthy control. ${ }^{[8,13,15,17]}$ However there is contrast in study by Hosen B et al. (2014) and Kavelaars et al. (2001), they have shown high serum sodium level in diabetic patients than in healthy control. ${ }^{[12,18]}$

The level of serum potassium were significantly increased in type 2 diabetic patients than healthy control, which is in agreement with Mohammad SS et al. (2005) and Mahboob T et al. (2008). ${ }^{[8,19]}$ In line with our study Hosen B et al. and Talabani $\mathrm{N}$ have shown increased potassium level in diabetic than in control but were not significant. ${ }^{[12,17]}$ On other hand, study by AlJameil $\mathrm{N}$ has shown hypokalemia in diabetics than in control which was also not significant. ${ }^{[13]}$ But study by Wang et al. has shown $1.2 \%$ of diabetic subjects have hyperkalemia and only $0.6 \%$ diabetes subjects have hypokalemia. ${ }^{[15]}$

Along with this, we found significantly elevated serum chloride level in type 2 diabetic patients than in healthy control. Similar to us, Hosen B et al., AlJameil $\mathrm{N}$ and Talabani $\mathrm{N}$ also shown the significantly elevated chloride level in diabetic patients than in control group. $[12,13,17]$

Furthermore we have established the relation of FPG with serum sodium, potassium and chloride in type 2 diabetic patients. There was significant negative correlation between FPG and serum sodium.
In contrast, significant positive correlation was found between FPG and serum potassium. Similarly positive and significant correlation of FPG was found with serum chloride. In concordance with our study, Parmer KS et al. has shown the similar correlation between FPG and serum potassium $(\mathrm{r}=0.235, \mathrm{p}=0.006)$ but no significant correlation with serum sodium $(\mathrm{r}$ $=-0.091, \mathrm{p}=0.296){ }^{[14]}$ Also study by AlJameil $\mathrm{N}$ has shown the same result as ours with serum sodium and chloride $(r=-0.244$, $\mathrm{p}=0.017)$ and $(\mathrm{r}=0.21, \mathrm{p}=0.04)$ respectively but not significant correlation with serum potassium $(\mathrm{r}=0.012, \mathrm{p}>0.05)$. [13]

The reason behind this abnormality can be explained as, normally sodium is reabsorbed in proximal convoluted tubule of kidney but in diabetes mellitus excessive urination happens due to hyperglycemia, can cause maximum excretion of sodium through urine was known to be the mechanical cause of decreased serum sodium level in type 2 diabetes. $^{[20]}$ The most common casual factor of chronic hyperkalemia in diabetes is the reduced tubular secretion of potassium due to syndrome of hyporeninemic hypoaldosteronism and also may be due to increase in potassium efflux from cell into serum in hyperosmolality ensuing hyperglycemia, which also causes relative increase in extracellular fluid derived from interstitial spaces. These osmotic effects have a diluting effect on the concentration of serum electrolytes which may have cause hyponatraemia. ${ }^{[6,21,22]}$ Another mechanism behind decreased serum sodium and increased serum potassium may be due to decreased activity of $\mathrm{Na}^{+}-\mathrm{K}^{+}$-ATPase in hyperglycemia. Hyperchloremia was more present in type II diabetic patients than non diabetic patients which could be due to hypertonicity. ${ }^{[23]}$

\section{CONCLUSION}

Upon the completion of this study we came up with the conclusion that there is decrease in plasma sodium level and 
increase in plasma chloride and potassium in people with type II diabetes. These disturbed distributions of electrolytes are associated with hyperglycemia which in turn is associated with pathophysiology of diabetes mellitus. Thus, management of type II diabetes must include electrolyte profile test to monitor increase or decrease of electrolyte to prevent the patient's risk of developing diabetes related complications like neuropathy, nephropathy and retinopathy.

\section{Acknowledgement: None}

\section{Conflict of Interest: None}

\section{Source of Funding: None}

\section{Ethical Approval: Approved}

\section{REFERENCES}

1. Zimmet P, Alberti KG, Shaw J. global and societal implications of the diabetes epidemic. $\quad$ Nature. 2001;414:7827.[PMID:11742409]

2. Thanpari C., Thakelmayum R \& Kumar R. Correlation of Lipid Profiles, Electrolytes and Antioxidant Status In Type 2 Diabetic Patients With Hypertension In Sikkimese Population: A Case Controlled Study. Jour. Of Med. Sci. \& Tech.1(2), pp 71-74.

3. Alberti K.G. and Zimmet P.. "Definition, diagnosis and classification of diabetes mellitus and its complications. Part 1: diagnosis and classification of diabetes mellitus, provisional report of a WHO Consultation." Diabet. Med. 1998; 15: 5393.

4. King H. and Rewers M. "Global estimates for prevalence of diabetes mellitus and impaired glucose tolerance in adults. WHO Ad Hoc Diabetes Reporting Group." Diabet. Care. 1993; 16: 157-7.

5. Hosen B, Buiyan AR, Hasan S, Hassan M, Uddin M. Estimation of Serum Electrolytes in non-Insulin Dependent (type 2) Diabetic Patients in Bangladesh, Scientific research journal (SCRJ). 2014;2(4):29-32.

6. Martini FH, Halyard RA. Fluid electrolytes and acid-base balance. In: Fundamentals of Anatomy and Physiology Interactive.
(Media Edition) 4th ed; USA; Person Education, Inc. 1998.

7. Ojiako OA, Chikezie PC. Blood $\mathrm{Na}+\mathrm{K}+$ and $\mathrm{Cl}$ - Levels of Hyperglycemic rats Administered with traditional Herbal Formulations, Pharmacognosy Communications. 2015;5(2):140-5.

8. Shahid SM, Rafique R, Mahboob T. Electrolytes and sodium transport mechanism in diabetes Pak. J Pharm. Sci. 2005; 18(2): 6-10.

9. Uribarri J, Oh MS, Carroll HJ. Hyperkalemia in diabetes mellitus. J Diabetes [9] Complications. 1990;4:03-07.

10. Albert V, Subramanian A, Rangarajan K et al. agreement of two different laboratory methods used to measure electrolytes. Journal of laboratory physicians. $2011 \mathrm{Jul}-$ Dec;3(2):104-109[PMID:22219564].

11. Sharma SP, Anjankar AP, Kale A. Comparison of glucose levels using glucometer and GOD-POD method in diabetic patients. International journal of clinical biochemistry and research. 2017;4(1):6-10.

12. Hosen B, Buiyan AR, Hasan $S$ et al. Estimation of serum electrolytes in type 2 diabetic patients in Bangladesh: Scientific research journal 2014;12: 2201-2796.

13. Al-Jameil N. Estimation of Serum Electrolytes in Diabetes Patients of Saudi Region. Life. Sci. J. 2014; 11(7): 378-380.

14. Parmar SK, Singh S, Singh GK. Role of hyperglycemia in the pathogenesis of $\mathrm{Na}^{+} / \mathrm{K}^{+}$disturbance. International J Res Med Sci.2016 Apr:4(4):1167-1171.

15. Wang $\mathrm{S}$, Xuhong $\mathrm{H}$, $\mathrm{Yu} \mathrm{L}$ et al. "Serum electrolytes relation to macrovascular complications in Chinese Patients with Diabetes mellitus." Cardiovas. Diabet. 2013; 12: 146-55. 5- Rao GM. Serum electrolytes and osmolality in diabetes mellitus. Indian J Med Sci 1992;46(10):3013.

16. Thapa K, Kunwar S, Thapa $\mathrm{S}$ et al. Assessment of the salivary glucose as a noninvasive test for diabetic patients. Int $\mathbf{J}$ Community Med Public Health 2019;6; 2289-94.

17. Talabani N. Serum electrolytes and lipid profiles in NIDDM patients from Kurdistan. Asian Journal of Medical Sciences 2015:6(3).

18. Kavelaars J, Tamsma JT, and Meinders AE. Hypernatremia in a non insulin dependent 
(type 2) diabetic patient with central diabetes insipidus. The Netherlands Journal of Medicine. 2001;58:150-4.

19. Shahid SM and Mahboob T. Electrolytes and NA+-K+-ATPase: Potential risk factors for the development of diabetic nephropathy. Pak J Pharm Sci 2008;21(2): 172-179.

20. Vallon V, Ritcher K, Blantz RC et al. Glomerular hyperfiltration in diabetes mellitus: a potential role of tubular reabsorption. J Am Soc Nephrol, 1999; 10(12): 2569-76.

21. Saito $T$, Ishikawa $S$, Higashiyama $M$. Inverse distribution of serum sodium and potassium in uncontrolled in patients with diabetes mellitus. Endocr. J. 1999;46(1):7580.

22. DeFronzo RA. Hyperkalemia and hyporeninemic hypoaldosteronism. Kidney Int. 1980; 17: 118-134 [PMID: 6990088].

23. Goodwill AE, Friday NN, Thom-Justus CA et al. influence of type 2 diabetes on serum electrolytes and renal function indices in patients. Journal of clinical and diagnostic research.2018 Jun, vol-12(6):BC13-BC16.

How to cite this article: Bohara J, Kunwar S, Poudel GA et.al. Serum electrolytes disturbances in type 2 diabetic patients. Int $J$ Health Sci Res. 2021; 11(7): 105-110. DOI: https://doi.org/10.52403/ijhsr.20210715 